276. バリアブルコリメータと電子線 の特性（4)

矩形照射野の等価正方形

広島市立安佐市民病院放射線科 $\bigcirc$ 森川賀根婎 ((Kaneo Morikawa)

（1）始めに： マイクロトロンは電子線用バリアブルコ リメータを装備して、容易に任意の矩形照射野が得られる。 X線の場合には、矩形照射野でのピーク吸仪線量を求める のにその照射野を等価な正方形照射野に换算する計算法が 使われており、その方法の電子線への適用を検討する。

（2）電子線ピーク線至内摷の可能性： 公称 $14 \mathrm{MeV} の$ 電子 線に対するピーク線量の照射野依存性を、図1亿示す。バ リアブルコリメータによる正方形照射野での测定結果であ る。ピーク線量は、設定線量に対する比で示す。図 1 中の 実線は、照射野寸法 $(\mathrm{X} \mathrm{cm})$ とピーク線量 (Dp) の測定値之 の関係を下式で表現したものであり、ての式の值と $14 \sim 6$ $\mathrm{MeV}$ 電子線に対寸る測定值との偏差は土2\%よりは小さい。 $D_{p}=\exp \left\{A_{0}+A_{1} \log (X)+A_{2} \log (X)^{2}+A_{3} \log (X)^{3}\right\}$ 前に報告 したように、コーンの場合には構造の違いによってピーク 線量の照射野依存性に不連続が生じ内挿が難しいが、バリ アブルコリメータの場合は不連続は小さく比較的正確に内 㨀できる可能性がある。

（3）等価正方形照射野換算法：X線の矩形照射野では、 ster ling の計算法 $(\mathrm{A} / \mathrm{P}$ 法)や、面棈法 ( $\sqrt{\mathrm{A}}$ 法) が使われる。乙 れらは、まず矩形照射野に対して等価な正方形照射野寸法 を計算し、次に正方形照射野で測定したピーク線量から矩 形照射野のピーク線量を内挿する。 $\mathrm{A} / \mathrm{P}$ 法では、矩形照射 野を面樍と周辺長との比が等しい正方形に置き換える。ま た、危法では、面積の等しい正方形に置き換える。またJARP 法では表によって等価正方形を求める。

（4）電子線への適用：ここでは、バリアブルコリメー 夕を使用する場合の電子線に対して、上記の各等価正方形 照射野換算法を適用し、測定値己比較する。

公称 $14 \mathrm{MeV}$ の電子線に対して矩形照射野で測定したピー ク吸収線量と、A $/ \mathrm{P}$ 法、在法、JARP法で計算した值の測定 值に対する偏差を、表 1 亿示す。測定值に対してどの計算 法もほぼ同程度の偏差を示し、14 $8 \mathrm{MeV}$ の電子線に対して $\pm 3.5 \%$ 程度以下、6 MeVに対して $\pm 6 \%$ 程度以下に納まる。

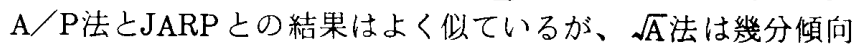
が異なる。いずれの場合も $6 \mathrm{MeV}$ で偏差が大きくなってい るが、測定値自体のばらつき（式 1 からの偏差）6 $6 \mathrm{MeV}$ に対する值は他のエネルギーよりも大きい。

（5）むすび： マイクロトロン用のバリアブルコリメー タでは、ピーク楾量は照射野寸法に対して比較的滑らかに 変化し、矩形照射野を等価的な正方形照射野に換算する方

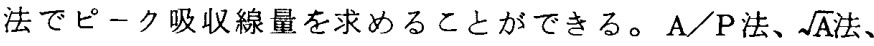
JARP法共に測定值からの偏差は同程度である。

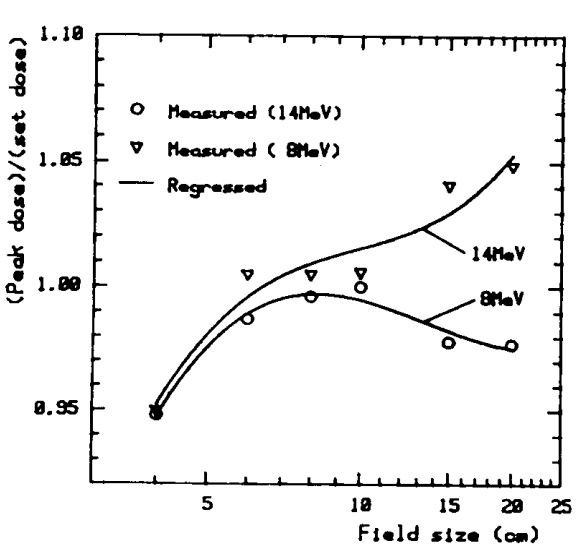

図 1 ピーク吸収線岳の测定值

\section{表 1 ピーク吸収線鼻の照射野依存性}

\begin{tabular}{|c|c|c|c|c|c|c|}
\hline \multirow{2}{*}{ 長讯 } & \multicolumn{6}{|c|}{ 知边 (ca) } \\
\hline & 4.0 & 6.0 & 8.0 & 10.0 & 15.0 & 20.0 \\
\hline $\begin{array}{r}4.0 \\
5.0 \\
8.0 \\
10.0 \\
15.0 \\
20.0\end{array}$ & $\begin{array}{l}0.948 \\
0.963 \\
0.967 \\
0.967 \\
0.967 \\
0.963 \\
0.962\end{array}$ & $\begin{array}{l}0.987 \\
0.996 \\
0.985 \\
0.987 \\
0.984\end{array}$ & $\begin{array}{l}0.996 \\
0.906 \\
1.9000 \\
0.9989 \\
0.989\end{array}$ & $\begin{array}{l}1.000 \\
1.001 \\
0.989\end{array}$ & $\begin{array}{l}0.978 \\
0.973\end{array}$ & 0.977 \\
\hline
\end{tabular}
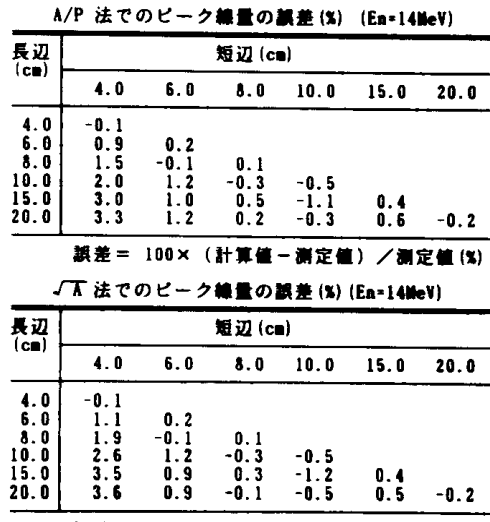

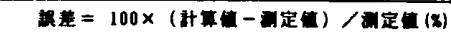

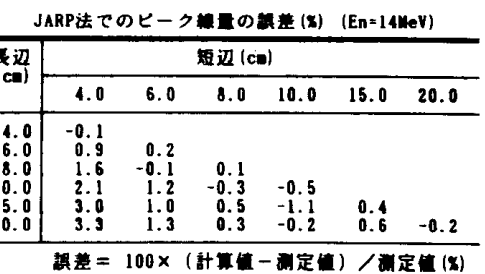

